Prethodno priopćenje

https://doi.org/10.31784/zvr.8.1.19

Datum primitka rada: 13. 1. 2020.

Datum prihvaćanja rada: 3. 2. 2020.

\title{
UTJECAJ SEZONSKIH OSCILACIJA NA KRETANJA CIJENE DIONICA U SEKTORU TURIZMA
}

\author{
Vedran Šarlija \\ Stručni specijalist poduzetništva, 51000 Rijeka, Hrvatska; e-mail: vedranv995@gmail.com
}

Vesna Buterin

Dr. sc., docentica, Sveučilište u Rijeci, Ekonomski fakultet Rijeka, Ivana Filipovića 4, 51000 Rijeka, Hrvatska; e-mail:vesna.buterin@efri.hr

\section{Denis Buterin}

Mr. sc., viši predavač, Veleučilište u Rijeci, Trpimirova 2/V, 51000 Rijeka, Hrvatska; e-mail: dbuterin@veleri.hr

\section{SAŽETAK}

Turizam i djelatnosti povezane s turizmom značajan su čimbenik hrvatskog gospodarstva, s jasnim naznakama nastavka takvih trendova i u budućnosti. Istraživanja pokazuju kako se udio turizma u hrvatskom bruto domaćem proizvodu povećao, a sve su više primjetna nastojanja za podizanjem kvalitete turističke ponude i produžavanja turističke sezone. Nositelji takvih inicijativa od kojih se očekuju povećani povrati u dugom roku zasad su uglavnom turistička poduzeća s najvećim financijskim potencijalom. U ovom radu autori istražuju je li kretanje cijene dionica takvih trgovačkih društava povezano s povećanim prihodima u vrijeme sezone, odnosno je li kretanje cijene povezano sa sezonskim oscilacijama ili je povezano s njihovom dugoročnom poslovnom politikom. Istraživanje je pokazalo da sezonske promjene imaju određeni utjecaj, ali nedovoljan da značajnije determiniraju kretanje cijene vrijednosnica na financijskom tržištu promatranih poduzeća. Unatoč značajnom povećanju prihoda, trend je silazan, a naznake njegovog obrata u kratkom i srednjem roku nisu uočene, što može ukazivati na nepovjerenje ulagača u takav oblik razvoja turističkih poduzeća.

Ključne riječi: financijska tržišta, turizam, tehnička analiza

\section{UVOD}

U središtu promatranja tehničke analize je kretanje cijene dionice i volumena prodaje kroz određene vremenske periode (Mishkin, 2005). Svrha provođenja tehničke analize je pravovremeno otkrivanje trenda ili smjera kretanja cijene dionice te predviđanje budućih događanja na financijskom tržištu sa svrhom potpore pri donošenju odluka o načinu i smjeru djelovanja na financijskim tržištima (Galetić et al, 2007). Da izračuni u tehničkoj analizi služe za mjerenje tržišnog trenda radi pravovremenog 
uključivanja u smjer trenda smatra i Schwager (1996). Suštinu tehničke analize moglo bi se sažeti u zaključak da je svrha njezine primjene shvaćanje tržišta prije obrata njegovih trendova (Kostolany, 1998). Premda na kretanja na financijskom tržištu značajno utječu i sentimenti sudionika povezani s vanjskim utjecajima, tehnička ih analiza isključuje kao što isključuje i ostale čimbenike koji bi se u drugim uvjetima i u drugačijim analizama mogli smatrati relevantnima (Shim et al, 2017). Tehnička analiza isključuje i učinke prelijevanja koji su na financijskim tržištima jače izraženi u vremenima krize (Živkov et al, 2018). Međutim, takvi se čimbenici često koriste kad se primjenjuje ex post tehnička analiza te kada se pokazatelji i trendovi i pripadajuća kretanja cijena i volumena prodaje uspoređuju s vanjskim i unutarnjim utjecajima za koje se pretpostavlja da bi mogli imati značajan utjecaj na cjenovna kretanja. Za ex post analizu u ovom radu odabrana su tri turistička trgovačka društva čije dionice kotiraju na vodećem i redovitom tržištu Zagrebačke burze: Plava laguna, Maistra i Valamar Riviera. Radi se o trgovačkim društvima koja raspolažu respektabilnim financijskim potencijalom i čiji se temeljni kapital kreće u rasponu od 1,3 do 1,7 milijardi kuna te o trgovačkim društvima koja posljednjih godina investiraju značajna sredstva u poboljšanje vlastitih kapaciteta. Uz to, upravo je sezonski karakter obavljanja turističke djelatnosti presudan za zapaženi porast prihoda u određenim ljetnim mjesecima što utječe na segmente ulagača, a time i na pojačanu potražnju i pozitivne cjenovne pomake. Treba ipak imati na umu da premda postoje autori koji hrvatsko tržišse vrijednosnih papira, odnosno Zagrebačku burzu smatraju modernim tržištem uređenim u skladu sa stečevinama Europske unije, ipak je ono nedovoljno razvijeno, odnosno usko zbog malog broja ulagača i plitko zbog malog broja naloga koji bi bili u stanju dovesti do značajnijih pomaka cijena i burzovnih indeksa te je posljedično nedovoljno likvidno i ne sasvim efikasno (Schabek et al, 2019; Olgić Draženović et al, 2016). Takva situacija očekivani je nastavak višedesetljetnog sustava krutog kreditno- distributivnog sustava financiranja uz veliku ulogu bankovnog aparata (Olgić Draženović et al, 2018). lako rezultate provedene ex post tehničke analize promatranih poduzeća treba sagledavati u okviru trenutne situacije na Zagrebačkoj burzi, oni ipak daju odgovor na pitanje utjecaja sezonskih oscilacija na kretanje cijene.

\section{POKAZATELII TEHNIČE ANALIZE ODABRANIH TURISTIČKIH PODUZEĆA (MAIS, PLAG, RIVP)}

\section{1 Trendovi}

Vremenski se trendovi klasificiraju u tri kategorije: glavni, koji je duži od jedne godine, srednjoročni koji traje do šest mjeseci te kratkoročni, od dva do tri mjeseca. Trend predstavlja smjer kretanja cijene dionice, a može se podijeliti na padajući odnosno medvjeđi, rastući odnosno bikovski te horizontalni ili, češće nazivan, bez trenda (Maričić, 2011). lako je fundamentalna analiza osnova za procjenu vrijednosti dionica poduzeća i donošenje investicijskih odluka (Prohaska et al, 2011), tehnička analiza bitan je alat za kratkoročne i dugoročne analize trendova na financijskim tržišstima i u brojnim slučajevima pruža upotrebljivije rezultate od fundamentalne analize (Lazibat i Matić, 2002). 
V. Šarlija, V. Buterin, D. Buterin: Utjecaj sezonskih oscilacija na kretanje cijene dionica u sektoru turizma Zbornik Veleučilišta u Rijeci, Vol. 8 (2020), No. 1, pp. 283-293

\section{Grafikon 1. Analiza trendova dionica MAIS, PLAG, RIVP}
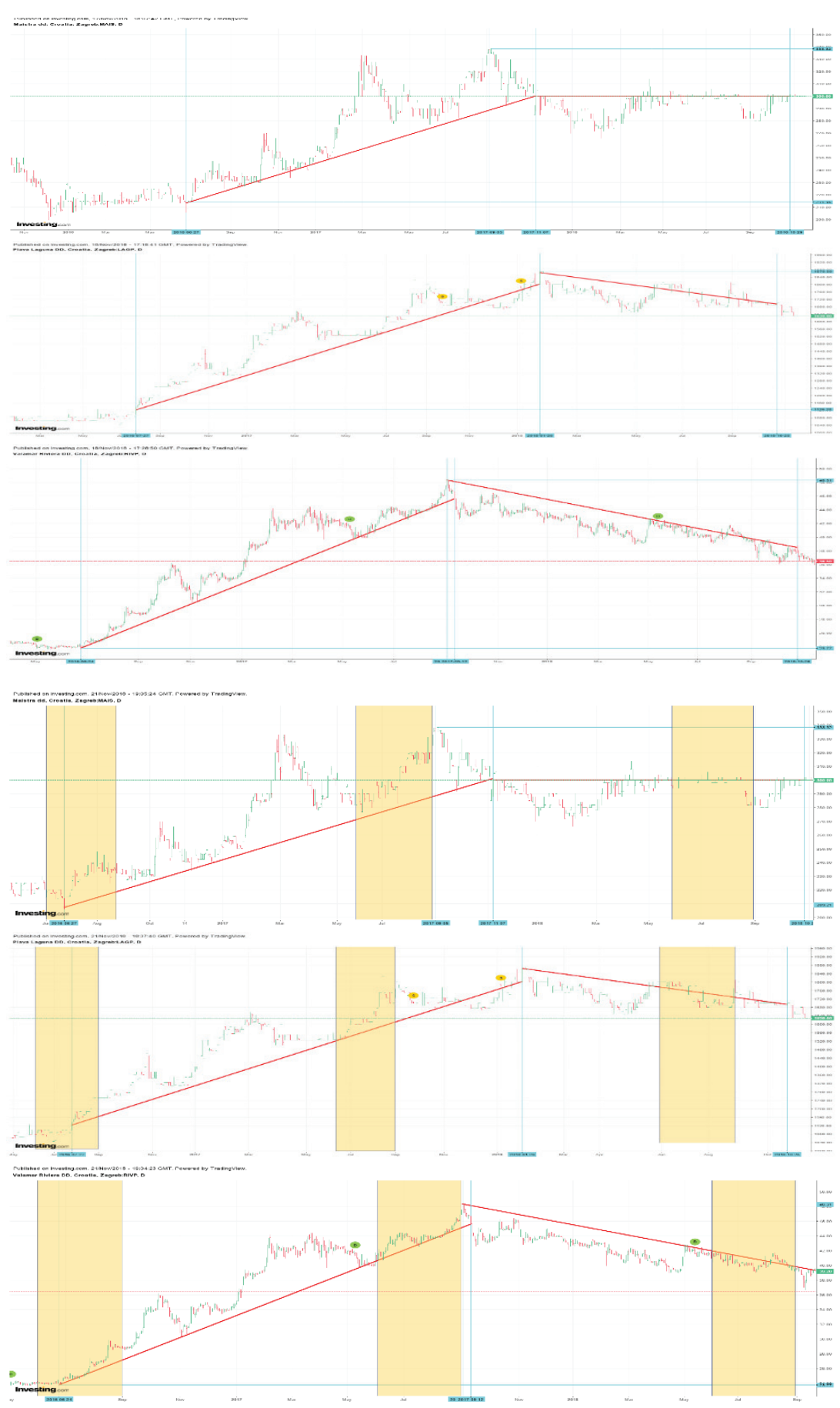

Izvor: Investing (2019) 
Promatrajući grafičke prikaze kretanja trenda dionica turističkih poduzeća Maistra d. d., Plava Laguna d. d. te Valamar Riviera d.d. vidljive su sličnosti u kretanju vrijednosti dionica poduzeća na tržištu vrijednosnica. Sve tri vrijednosnice imaju rastući trend u promatranom razdoblju s početkom promatranja trenda u lipnju 2016. godine. Obrat kretanja smjera trenda se događa u kratkom vremenskom periodu za sve promatrane dionice. Uzlazni trend dionice MAIS promatran je u razdoblju od 498 dana te je u tom vremenskom periodu vrijednost dionice porasla s 207,08 kn po dionici na 301,00 kn što je povećanje od 93,92 kn po dionici odnosno $45,35 \%$. Najviša postignuta cijena dionice za vrijeme uzlaznog trenda je $338,45 \mathrm{kn}$. Razdoblje uzlaznog trenda završava 7. 11. 2017. kada započinje razdoblje bez trenda. $U$ tom razdoblju dolazi do povremenog smanjivanja vrijednosti dionice, ali se cijena redovito ponovno vraća na početnu razinu. Razdoblje s neizraženim trendom traje 335 dana, odnosno do kraja promatranog razdoblja što je vidljivo iz grafičkog prikaza.

Uzlazni trend dionice PLAG promatran je u razdoblju od 548 dana. U tom razdoblju se cijena po dionici povećala sa $1100,00 \mathrm{kn}$ na $1870,00 \mathrm{kn}$ po dionici. $U$ promatranom razdoblju dolazi do povećanja vrijednosti dionice za 770,00 kn po dionici odnosno izraženo u postotku povećanje od $70 \%$. Silazni trend te period medvjeđeg tržišta promatran je u razdoblju od 272 dana kada se cijena dionice smanjila sa 1870,00 kn po dionici na 1700,00 kn po dionici što je promjena od 170,00 kn ili u postotku 9,10\%. Promatrajući potez dijeljenja dionice te smanjenja cijene dionice sa 4465,00 kn na 1088,00 kn po dionici uočljiv je nastavak dugoročnog uzlaznog trenda na nižoj razini cijene. Nadalje, vidljivo je značajno povećanje trgovine dionicom što je dodatno potaknulo rast njene vrijednosti na tržištu. Uzlazni trend dionice RIVP traje 445 dana. Cijena vrijednosnice bila je $23,93 \mathrm{kn}$ na početku uzlaznog trenda te se podigla na najvišu razinu od $48,00 \mathrm{kn}$ po vrijednosnici u promatranom razdoblju. Cijena se povećala za 24,07 kn po vrijednosnici odnosno izraženo u postotku 100,53\%. Završetkom uzlaznog trenda slijedi obrat tržišta te silazni trend čije je trajanje do kraja promatranog razdoblja odnosno na grafičkom prikazu 417 dana te je također dugoročni trend. Tržište je medvjeđe te vrijednosnice bilježe smanjenje vrijednosti na tržištu i to sa $48,00 \mathrm{kn}$ na $37,80 \mathrm{kn}$. Vrijednost dionice se smanjila za 10,20 kn što u postotku iznosi $21,25 \%$.

Na grafikonu 1 označeni su vremenski periodi trajanja turističke sezone u područjima djelovanja promatranih turističkih poduzeća. Vidljivi su porasti cijena dionica u istaknutim vremenskim periodima, ali rast ne prestaje po isteku perioda već se kontinuirano nastavlja. Utjecaj sezonskih oscilacija nema snagu utjecaja na kretanje vrijednosti dionica na tržištu. Utjecaj sezonskih oscilacija na dionice je ograničen drugim čimbenicima određivanja vrijednosti dionica na financijskim tržištima. Povoljni utjecaj mogu doprinijeti pozitivnom smjeru kretanja cijena na tržištu kao što negativni utjecaju mogu doprinijeti negativnim kretanjima smjera dionica no nemaju dovoljnu snagu kako bi promijenili kontinuirani smjer kretanja vrijednosti dionica na financijskim tržǐstima.

\subsection{Pomični prosjeci}

Pomični prosjek u tehničkoj analizi je pokazatelj koji se koristi kako bi se slijedili trendovi i pravovremeno predvidjele promjene njihova smjera. Svrha analize pomičnih prosjeka je identificirati i signalizirati početak novog trenda ili obrat postojećeg trenda (Edwards et al, 2007). Oni predstavljaju prosjeke određenog skupa podataka (Prohaska, 1997). 


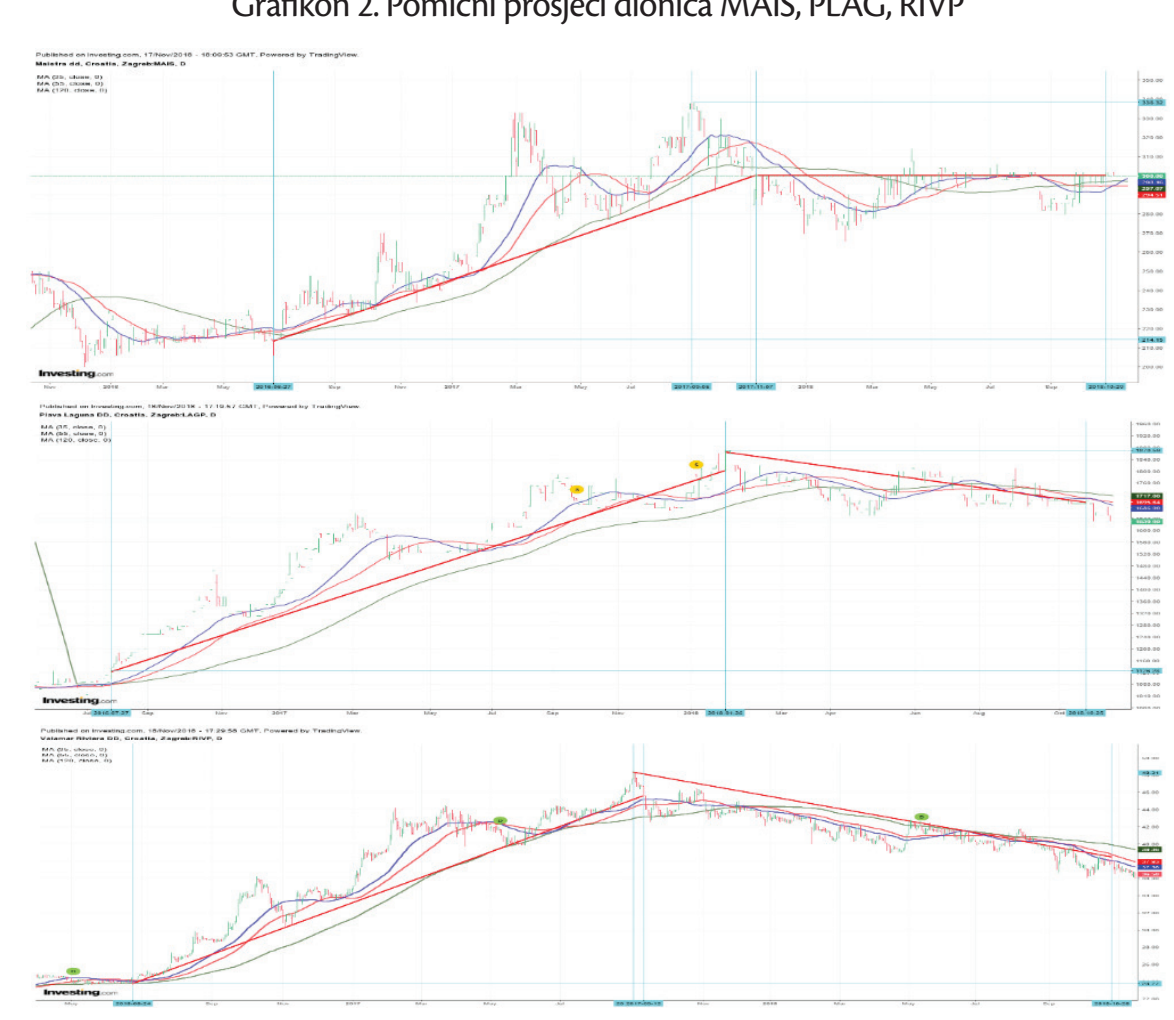

Izvor: Investing (2019)

Pomični prosjeci dionica promatrani su u razdoblju od 35, 50 i 120 dana. Promatrani prosjeci od 35 i 50 pokazuju ranije signale promjene na tržištu dok pomični prosjek od 120 daje kasnije, ali točnije signale. Presijecanje pomičnih prosjeka u tri točke potvrđuje obrat tržišta te promjenu smjera kretanja trenda. Promatrajući dionicu MAIS vidljiva su česta te naglašena presijecanja prosjeka s kraćim vremenskim intervalom do čega su dovele veće promjene u vrijednosti dionice u kratkom periodu. Najizraženija su zadnja dva presijecanja prije obrata tržišta i presijecanja svih triju pomičnih prosjeka. Promatrajući kretanje pomičnih prosjeka dionica PLAG I RIVP uočavaju se manje amplitude zbog manje izraženih razina promjena cijene dionica. U silaznom trendu promatranih dionica vidljivo je kretanje prosjeka u vrlo malim razmacima bez naglih oscilacija određenog pomičnog prosjeka. Kreću se kontinuiranim tokom, dok pomični prosjeci kod dionice MAIS imaju izražajnije amplitude razdoblja bez izraženog trenda za razliku od ostalih promatranih dionica kojima je trend silazan.

\subsection{Analiza momentuma}

Kod analize oscilatora, momentumom se mjeri brzina cjenovnih promjena tako da se cijene za određeno fiksno razdoblje neprekidno oduzimaju. Momentum je osnovni oblik analize oscilatora, a njime se mjeri razlika između cijena u dva vremenska razdoblja (Murphy, 2007). Promatranjem 
kretanja linije momentuma može se uočiti ubrzava li rastući trend ili su kapitalni dobici jednaki onima iz prethodnog razdoblja te započinje li silazni trend. Za učinkovitije prepoznavanje obrata trenda potrebno je koristiti duži momentum.

Grafikon 3. Momentumi dionica MAIS, PLAG, RIVP

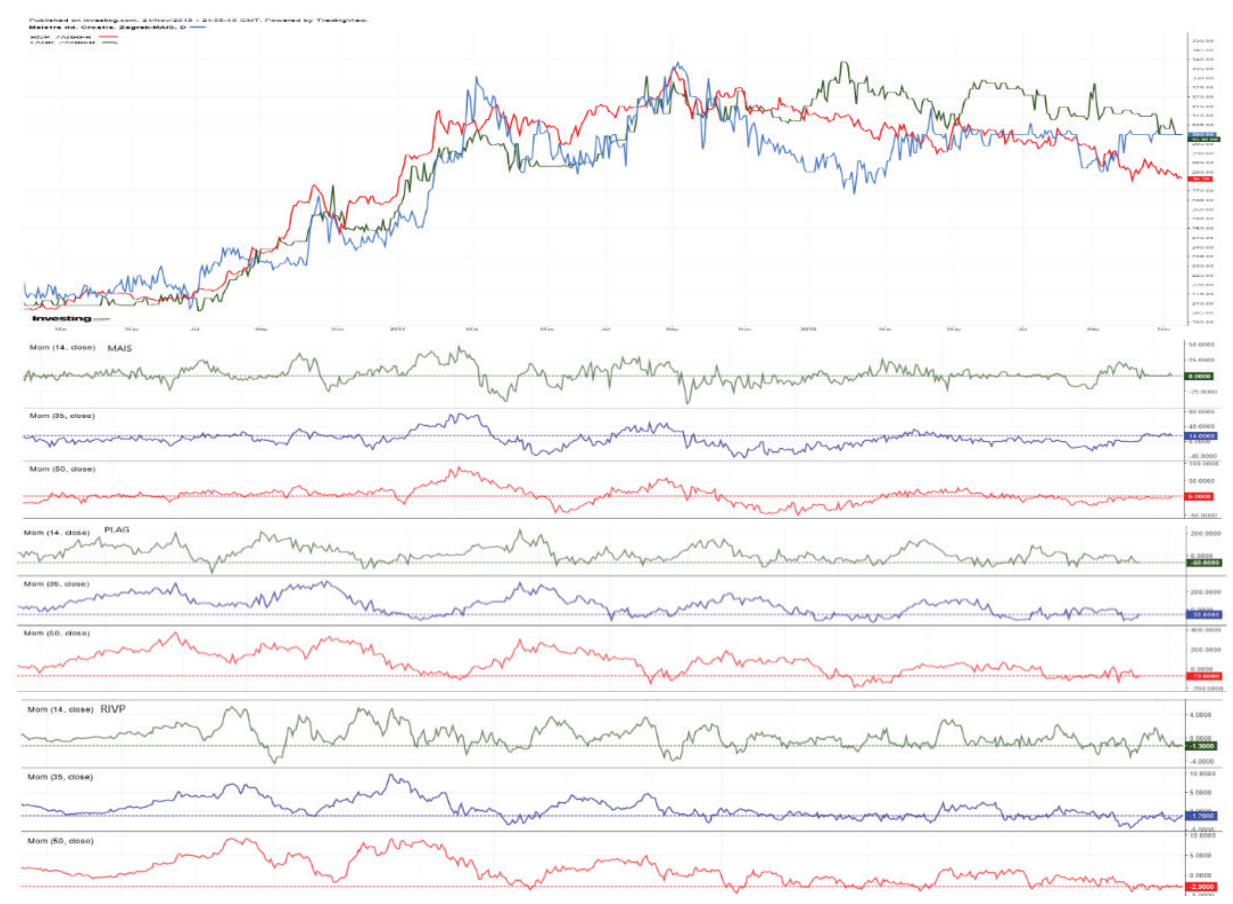

Izvor: Investing (2019)

Na grafikonu 3 linijski je prikazano usporedno kretanje cijene dionica na tržištu kroz promatrano razdoblje. Vidljivo je kako u određenim vremenskim periodima dionice različitih poduzeća ostvaruju rast vrijednosti u sličnoj mjeri te slijede uzlazni trend što obilježava bikovsko tržište. Može se reći kako sektor turizma ostvaruje rast vrijednosti poduzeća na financijskom tržištu. Završetkom uzlaznog trenda dolazi do razilaženja i neravnomjernog kretanja vrijednosti dionica promatranih poduzeća. Dolazi do obrata tržišta na medvjeđe i mijenja se smjer kretanja trenda. Dionica MAIS i RIVP počinju istovremeno gubiti na vrijednosti dionice $s$ tim da je smanjenje vrijednosti izražajnije kod dionice MAIS koja se kroz vremenski period vraća na prethodnu razinu te njezin trend ostaje neizražen dok dionica RIVP na početku postiže manje smanjenje vrijednosti koje se kontinuirano nastavlja bez naznaka obrata te trend ostaje negativan. Dionica poduzeća PLAG ostvarila je duži vremenski rast od ostalih promatranih poduzeća tako da se obrat dogodio nešto kasnije nakon čega slijedi kontinuirani pad vrijednosti. Promatrajući momentume poduzeća koji su promatrani u vremenskim periodima od 14, 35 i 50 dana primjećuju se sličnosti između snage trenda određene promatrane dionice. Za vrijeme bikovskog tržišta momentum je izražajniji te ukazuje na jačanje uzlaznog trenda u određenim vremenskim periodima. Momentumi ukazuju na jačanje snage uzlaznog trenda dionica PLAG i RIVP na početku uzlaznog razdoblja. Primjećuje 
se kako momentum od 14 ima vrlo izražene promjene u smjeru kretanja krivulje što je uzrokovano naglim promjenama u cijeni koje utječu na momentum te se promatraju duži momentumi kako bi se postigla relevantnost informacija. Momentumi od 35 i 50 kreću se sličnim putanjama te dobivaju na snazi u sličnim vremenskim periodima. Momentum dionice MAIS nešto kasnije od ostalih dobiva na snazi uzlaznog trenda koji je slabije izražen jer je rast kontinuiran u manjim stopama. Završetkom bikovskog tržǐsta svi promatrani momentumi se kreću uz linije cijene bez većih oscilacija. Tržišni trend je stagnirajući ili negativan, ali njegova snaga nije naročito naglašena što se iz grafikona prilično jasno može vidjeti.

\subsection{Indeks relativne snage}

$\mathrm{U}$ analizi oscilatora, često je korišten $\mathrm{i}$ indeks relativne snage koji umanjuje distorzije koje se kod naglih promjena cijene javljaju kod momentuma. Indeks relativne snage fiksira momentum u raspon od 0 do 100 (Agram brokeri, 2008). U interpretaciji indeksa relativne snage postoji problem takozvanog neuspješnog zamaha, koji se odnosi na slučajeve kada je indeks ispod 30 ili 70 bodova, odnosno kada u rastućem trendu vrh indeksa relativne snage ne uspije premašiti prethodni vrh te kada doseže niže dno od prethodnog. Ako je trend padajući, proces je obrnut: novi vrhovi i nova dna viša su od prethodnih (Šarlija et al, 2019).

Grafikon 4. Indeks relativne snage dionica MAIS, PLAG, RIVP

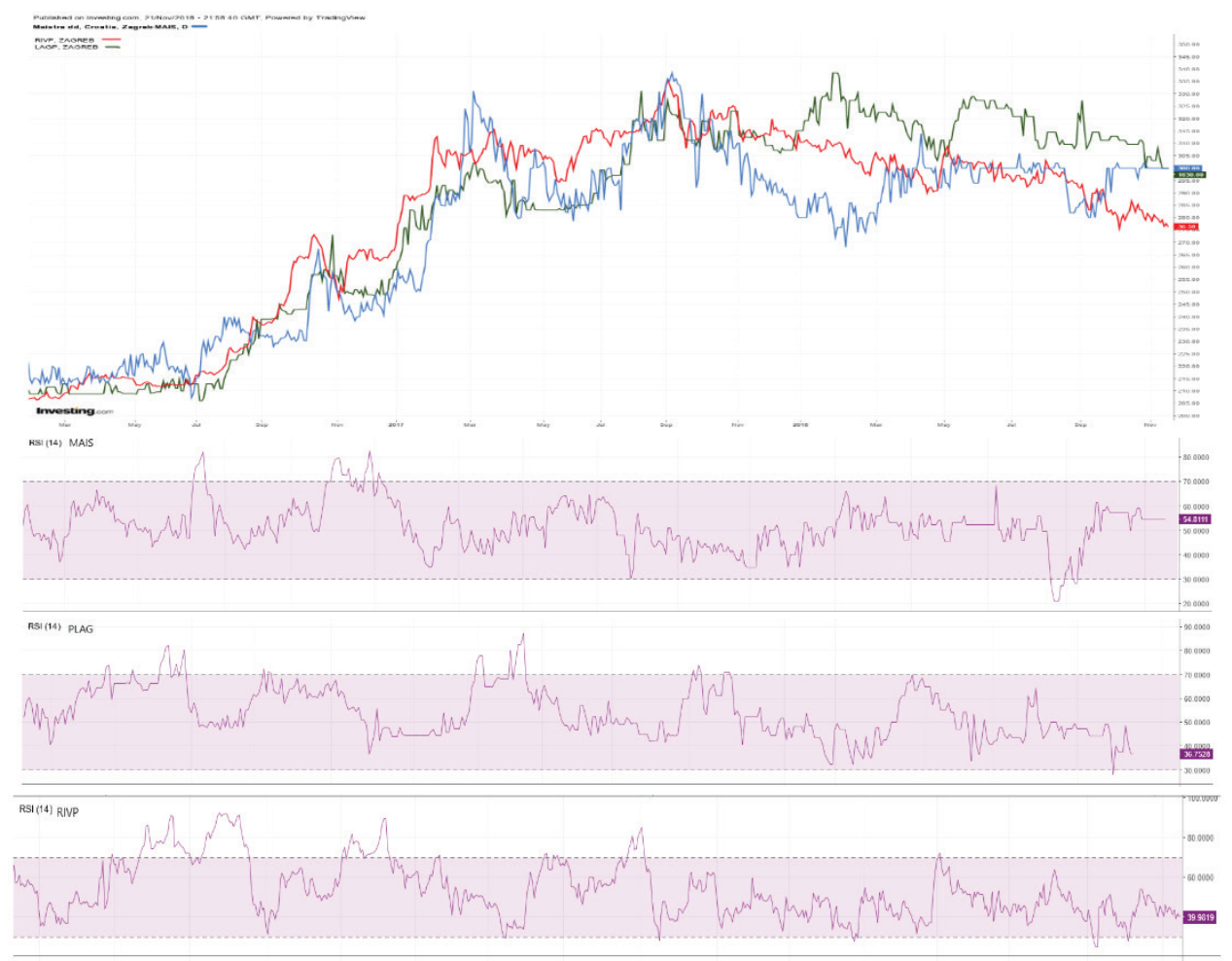

Izvor: Investing (2019) 
Promatrajući RSI dionica zaključuje se kako dionice imaju sličnosti u kretanju RSI oscilatora. Početkom uzlaznog trenda dolazi do povećane potražnje za dionicama što se vidi na grafovima indeksa relativne snage gdje linija premašuje gornju granicu raspona kod sve tri dionice. Nakon proboja gornje granice dolazi do pada te se linija počinje spuštati prema donjoj granici oscilatora, ali samo kod dionice RIVP ona dotiče donju granicu raspona dok kod dionica MAIS i PLAG ona ima blaži pad nakon čega slijedi ponovni rast. Pokazatelj dionice MAIS prelazi još jednom gornju granicu raspona te se nakon toga kreće unutar raspona sve do silaznog trenda pred kraj promatranog razdoblja kada prelazi donju granicu raspona. Dionice PLAG i RIVP imaju izražajnije promjene u dužem periodu u odnosu na prethodnu dionicu, ali i kod tih dionica se primjećuje zaokret tržišta a pred kraj razdoblja njihove linije indeksa relativne snage se kreću uz donju granicu raspona te imaju tendenciju prelaska donje granice.

\subsection{MACD pokazatelj}

Oscilator MACD (Moving average convergence/divergence) pokazuje odnos između dvaju pomičnih prosjeka cijena, a služi za otkrivanje promjena u snazi, pravcu, momentumu i trajanju trenda (Eric et al, 2009). Brža MACD linija rezultat je dvaju eksponencijalno vaganih pomičnih prosjeka zaključnih cijena, dok sporija odnosno signalna linija predstavlja eksponencijalno vagani prosjek u posljednjih 9 razdoblja (Murphy, 2007).

Grafikon 5. MACD pokazatelj dionica MAIS, PLAG, RIVP

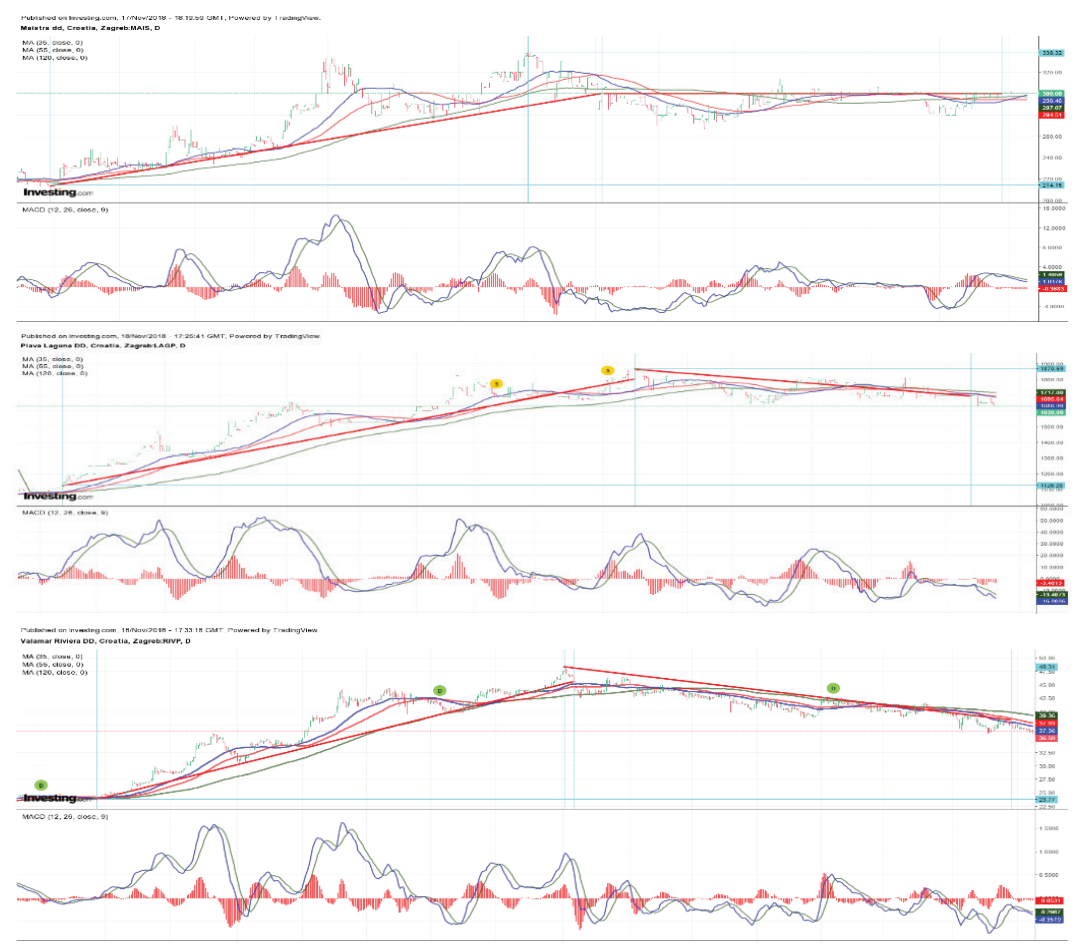

Izvor: Investing (2019) 
Promatranjem MACD oscilatora za dionice vidljivo je smanjenje raspona amplituda s odmakom vremenskog perioda. U razdoblju bikovskog tržišta amplitude su veće te su razlike u cijeni izraženije a kupovni i prodajni signali naglašeniji u kraćim razdobljima. Presijecanje linije MACD i signalne linije najavljuje obrat kretanja cijene što se vidi iz grafičkih prikaza. Dionica MAIS u periodu uzlaznog trenda iskazuje sličnosti s kretanjima ostalih promatranih dionica na tržištu što nije slučaj nakon promjene tržišta jer dionica ima neizražen trend te se linija signala i MACD kreću paralelno uz manje promjene u kojima se presijecaju. Dionice PLAG i RIVP imaju izražajnije amplitude i za vrijeme medvjeđeg tržišta u fazi silaznog trenda što je vidljivo na grafikonu 5 te vrijednosno u promjenama cijene tijekom promatranog vremenskog razdoblja.

\section{ZAKLJUČAK}

Promatrajući duži vremenski period vidljiva je promjena na tržištu koja se odrazila na cijene dionica. Upotrebom alata za provođenje ex post analize dobiveni su rezultati koji su korišteni u donošenju konačnih zaključaka. Kretanjem trendova na tržištu može se utvrditi pozitivni trend u prvom dijelu promatranog razdoblja te bikovsko tržište i pozitivan smjer kretanja cijena dionica. Uvjeti na tržištu bili su vrlo povoljni za ulaganje te su razlike u cijeni bile izražajnije. U kratkom vremenskom periodu dolazi do obrata tržišta te sve promatrane dionice mijenjaju smjer kretanja trenda. Dionica MAIS ostaje s neizraženim trendom dok dionice PLAG I RIVP imaju negativan trend. Promatranjem pomičnih prosjeka nisu vidljive naznake promjene trenda u kratkom i srednjem roku kao ni promjene na tržištu. Pomični prosjeci se kreću kontinuiranim putanjama bez naglih odstupanja. Promatranjem momentuma vidljiva su izražajnija kretanja u uzlaznom trendu dok u fazi silaznog trenda momentumi nemaju veliku snagu što potvrđuje blagi pad na tržištu bez tendencija naglih promjena. Indeksi relativne snage se kreću uz donje razine promatranih raspona. Indeks relativne snage umanjuje distorzije momentuma te se može promatrati s većom vjerodostojnošću. MACD oscilator nakon uzlazne faze s naglašenim amplitudama te izraženim signalima i promjenama $u$ vrijednosti slabi te nema naglašene promjene kao i jako izražene signale. Promatranjem perioda turističke sezone u usporedbi s primijenjenim pokazateljima vidljivo je kako je turistička sezona samo jedan od čimbenika utjecaja na cijene dionica turističkih poduzeća na financijskim tržištima te kako ustvari veći broj čimbenika utječe na formiranje cijene kao i smjer kretanja cijene. Promatrajući turistička poduzeća te kretanje dionica na financijskim tržištima zaključuje se kako je tržišste u silaznoj fazi te dolazi do smanjenja vrijednosti. Nisu uočene naznake obrata tržišta u kratkom i srednjem roku te se pretpostavlja daljnji smjer kretanja kontinuiranim trenutnim tokom bez većih oscilacija te naglih zaokreta u vrijednostima dionica turističkih poduzeća na financijskim tržištima. Zaključno, uzimajući u obzir ograničenja malog uzorka i stanja na hrvatskom tržištu vrijednosnih papira, može se reći kako povoljne sezonske oscilacije zasad nemaju značajnijeg utjecaja na kretanje cijene dionica vrijednosnih papira.

* Ovaj rad je financiralo/sufinanciralo Sveučilište u Rijeci projektima uniri-drustv-18-27 i uniridrustv-18-61. 


\section{LITERATURA}

Agram brokeri (2008) Uvod u tehničku analizu, Zagreb, Agram brokeri

Edwards D. R., Magee J., Bassetti W. H. C. (2007) Technical analysis of stock trends 9th edition, New York: Taylor \&Francis Group

Ekonomski institut, Zagreb (2013), Sektorske analize, Turizam, 2, 19, ur. Božić, Lj.

Ekonomski institut, Zagreb (2018), Sektorske analize, Turizam, 7, 65, ur. Rašić Bakarić, I.

Eric, D., Andjelic, G., Redzepagic, S. (2009) „Application of MACD and RVI indicators as functions of investment strategy optimization on the financial market." U: Zbornik radova Ekonomskog fakulteta u Rijeci, 27(1), p. 171-196

Galetić, F., Herceg, T., Morić Milovanović, B. (2007) „Mikroekonomska analiza tržišta hrvatskih dioničkih investicijskih fondova“, U: Zbornik Ekonomskog fakulteta u Zagrebu, 5(1), p. 431-437

https://www.investing.com/equities/plava-laguna-dd (30.11.2019.)

https://www.investing.com/equities/maistra-dd (30.11.2019.)

https://www.investing.com/equities/valamar-riviera-dd (30.11.2019.)

Kostolany, A. (1998), Izazovi burze, Zagreb: LMN

Lazibat, T., Matić, B. (2002), "Fundamentalna i tehnička analiza cijena na terminskim tržištima, Ekonomski pregled" U: Ekonomski pregled, 53(5-6), 507-524

Maričić, Z., (2011) „Forex - karakteristike, trgovanje, tehnička i fundamentalna analiza“. U: Zbornik radova Međimurskog veleučlišsta u Čakovcu, 2(1), 55-68

Mishkin, F. S. (2010), Ekonomija novca, bankarstva i financijskih tržišta, Zagreb, Mate

Murphy, J. J. (2007), Tehnička analiza financiijkih tržišta: sveobuhvatni vodič za trgovinske metode i njihovu primjenu, Zagreb: Masmedia

Olgić Draženović, B., Maradin, D., Buterin, V. (2016), Tax framework of Croatian financial system, 5th International Scientific Symposium “Economy of Eastern Croatia - Vision and Growth", procceedings / Mašek Tonković, A., Sveučilište Josipa Jurja Strossmayera u Osijeku, Ekonomski fakultet Osijek, 2016, 1060-1068

Olgić Draženović, B., Buterin, V., Buterin, D. (2018), Strukturne reforme zemalja CEE u tranzicijskom razdoblju - pouke i zaključci, Zbornik Veleučilišta u Rijeci, Vol, 6, No. 1, 121-142

Prohaska, Z. (1997) Mjesto iznačenje tehničke analize u investicijskoj industriji. Računovodstvo, financije i revizija u suvremenim gospodarskim uvjetima, Pula: Hrvatska zajednica računovođa i financijskih djelatnika

Prohaska, Z., Uroda, I., Suljić, S. (2011) SP - A Computer Program for Fundamental Analysis of Stocks, Čičin-Šain, M., Uroda, I, Turčić-Prstačić, I. i Sluganović, I. (ur.) Proceedings of the 34th International convention on information and communication technology, electronics and microelectronics, Vol. IV, Computers in education, MIPRO - hrvatska udruga za informacijsku i komunikacijsku tehnologiju, elektroniku i mikroelektroniku (Croatian Society for Information and Communication Technology, Electronics and Microelectronics), Rijeka, str. 88-92.

Schabek, T., Olgić Draženović, B., Mance, D. (2019), Reaction of Zagreb Stock Exchange CROBEX Index to macroeconomic announcements within a high frequency time interval, Zbornik radova Ekonomskog fakulteta u Rijeci: časopis za ekonomsku teoriju i praksu, Vol 37, No 2., 741-758

Schwager, D. J. (1996) Shwager on Futures: TehnicalAnalysis, New York: JohnWiley\&Sons, Inc

Shim, H., Kim, M. H., Ryu, D. (2017), „Effects of intraday weather changes on asset returns and volatilities", Zbornik radova Ekonomskog fakulteta u Rijeci: časopis za ekonomsku teoriju i praksu, Vol 35, No 2. https://doi.org/10.18045/ zbefri.2017.2.301

Šarlija, V., Vuraić-Kudeljan, M., Buterin, D. (2019), Protokoli tehničke analize u razlučivanju potcijenjenosti od niske cijene, Zbornik Veleučilišta u Rijeci, Vol, 7, No. 1, 287-300

Živkov, D., Njegić, J., Momčilović, M. (2018), „Bidirectional spillover effect between Russian stock index and the selected commodities", Zbornik radova Ekonomskog fakulteta u Rijeci: časopis za ekonomsku teoriju i praksu, Vol 36, № 1. 


\title{
THE INFLUENCE OF SEASONAL OSCILLATIONS ON STOCK PRICE TRENDS IN THE TOURISM SECTOR
}

\author{
Vedran Šarlija \\ Professional Specialist of Entrepreneurship, 51000 Rijeka, Croatia; \\ e-mail:vedranv995@gmail.com
}

Vesna Buterin

PhD, Assistant Professor, University of Rijeka, Faculty of Economics in Rijeka, Ivana Filipovića 4, 51000 Rijeka, Croatia; e-mail: vesna.buterin@efri.hr

\section{Denis Buterin}

MSc, Senior Lecturer, Polytechnic of Rijeka, Trpimirova 2/V, 51000 Rijeka, Croatia; e-mail: dbuterin@veleri.hr

\begin{abstract}
Tourism and tourism-related activities are a significant factor in the Croatian economy, with clear indications of the continuation of such trends in the future. Research shows that the share of tourism in the Croatian gross domestic product has increased, and efforts to raise the quality of the tourist offer and extend the tourist season are becoming more noticeable. Holders of such initiatives, which are expected to increase long-term returns, are currently mostly tourism companies with the highest financial potential. In this paper, the authors investigate whether the movement in the stock price of such companies is associated with increased revenues during the season, that is, whether the price movement is related to seasonal fluctuations or is related to their long-term business policy. The research has shown that seasonal changes have some influence, but not sufficient to significantly determine the price movement of securities in the financial market of observed enterprises. Despite a significant increase in revenue, the trend is downward and indications of its turnaround have not been observed in the short and medium term, which may indicate investors' lack of confidence in this form of tourism business development.
\end{abstract}

Key words: financial markets, tourism, technical analysis 